\title{
Innovation Capacity Index Assessment of Natural Rubber Latex Based Industry: Comparative Study of Indonesia and Malaysia and Its Implications on the Development of The Industry
}

\author{
Dadang Kurnia $^{1 *} \quad$ Marimin $^{2} \quad$ Uhendi Haris $^{3} \quad$ Sudradjat $^{4}$ \\ 1.School of Business, IPB University, Jln Pajajaran, Bogor 16151 Indonesia PO box 16151, Bogor, Indonesia \\ 2.Faculty of Agricultural technology, IPB University, Jln Raya Darmaga, Bogor 16680 Indonesia, \\ PO box 16151, Bogor, Indonesia \\ 3.Rubber Association of Indonesia, Jln Cideng Barat 62-A, Jakarta 10150, Indonesia \\ 4.Faculty of Agriculture, IPB University, Jln Raya Darmaga, Bogor 16680, Indonesia PO box 16680, Bogor,
} Indonesia

\begin{abstract}
The purpose of this study is to compare the natural rubber latex-based industry innovation capacities of two natural rubber producing countries namely Malaysia and Indonesia, and its implications for the improvement of the industry. Using purposive sampling method with the natural rubber industry experts from both countries as the respondents. This study was conducted through several stages, including: 1) determining attributes for each innovation capability dimensions: organization, process, service, product and marketing. These attributes are based on literature review and validated by experts, 2) distribution of questionnaires to experts in Indonesia and Malaysia, 3) Analysis of the innovation capacity index using multidimensional scaling. The Indonesia innovation capacity index is 60.22 , while it is 78.80 for Malaysia. This shows that overall, in terms of its ability to innovate the industry in Indonesia is still lagging behind Malaysia. In addition, all attributes for each capability: organizational, processes, services, product/product development and marketing innovation capability, Indonesia is also still lagging behind Malaysia. It only compares the two natural rubber producing countries, namely Indonesia and Malaysia. The implication for Indonesia is the need of government's political commitment, legal direction for innovation, legal certainty, strong institutions, institutional restructuring to facilitate coordination, improvement the quality of human resources and ease of financial access. The research contributes in finding 25 attributes of innovation capabilities. Further, this study also maps the comparative capabilities of Malaysian and Indonesian innovations for each latex-based natural rubber industry innovation capability dimension, and the steps to improve the innovation progress, specifically for Indonesia in order to catch up.

Keywords: Innovation capacity, capacity index, Latex based industry, Multi-dimensional scaling and rubber latex DOI: $10.7176 / \mathrm{EJBM} / 12-11-05$

Publication date: April $30^{\text {th }} 2020$

\section{Introduction}

Although Indonesia is known as a country with the largest natural rubber planting area in the world, the value added generated from the industry is still inferior to Malaysia. With plantation area of around 3.5 million hectares, the export value of Indonesia's natural rubber industry was only USD 7.7 billion in 2017, and it reached USD 6.4 billion in 2018 (Ditjenbun, 2017; Gapkindo, 2019). On the other hand, with plantation area of 602 thousand ha, Malaysia's natural rubber industry contributed RM 40.36 billion to economy (or equivalent to USD 9.7 billion) (LGM, 2019).

IRSG (2019) shows that during the period of 2011 to 2018, the average of Indonesia's natural rubber production was at 2.73 million tons, while the domestic consumption reached 538 thousand tons. This implies that Indonesian rubber industry relies on primary products, namely producing raw rubber. In addition, the absorption of the domestic manufacturing industry which converts raw rubber into rubber goods is only around $16 \%$. While Malaysia's manufacturing industry is able to absorb $52 \%$ of its total natural rubber production (Dekarindo, 2019). This condition causes foreign exchange earnings, increase in value addition, and employment absorption becomes not optimal (RPN, 2011). To this day, the world only considers Indonesia as producing countries or supplier of rubber raw materials for developed countries who produce rubber finished goods (Fauzi 2013). Therefore, revitalization of the domestic downstream rubber industry can be done to reduce the consequences from the decreasing natural rubber market price, which results in disruption of the industry players' income stability (especially rubber planters). Moreover, it will also increase the domestic rubber absorption or consumption for non-traditional uses (Gapkindo, 2016; Erni, 2013). Non-traditional Latex based rubber industries such as gloves, rubber yarn, teats, condoms and medical devices needs to be developed. In addition, there are several innovative products which can be potentially developed commercially, namely rubberized asphalt, earthquake resistant rubber, dock fenders and rubber water tanks. These types of products are alternative solutions to increase value addition to Indonesia's natural rubber industry.
\end{abstract}


While Indonesia still relies on primary products, Malaysia has transformed into a developed country for its downstream industry. Malaysia is not only known as a natural rubber producer, but also as a user (customer) of natural rubber raw materials for its manufacturing industry which is rapidly developing. Moreover, Malaysia is the number one latex user country in the world. It is also one of the 6 (six) major countries that use natural rubber and included in the list of 10 (ten) major users of both natural rubber and synthetic rubber. As a country whose focus is to develop its rubber industry, Malaysia is known as the largest industrial country and producer of gloves, condoms and Nitrile Butadiene Rubber (NBR) in the world, as well as rank number 2 (two) as the world's yarn and chattered producing country.

As a comparison, the performance of Indonesia's rubber glove industry is currently not encouraging, out of 11 (eleven) companies which is registered in the Ministry of Industry, only 6 (six) companies are still actively operating (Dekarindo, 2017). Further, the realization of Indonesia's glove production tends to continue to decline. The production of gloves was 10.36 billion pieces in 2010 and decreased by $23 \%$ into 7.1 billion pieces in 2016 . The value of Indonesia's exports has also declined from USD 261 million in 2011 to USD 232 million in 2016. On the contrary, the value of imports increased from USD 14.4 million in 2011 to USD 22.5 million in 2016. Meanwhile, Malaysia's rubber glove industry continues to grow. In 2011, Malaysia produced 30.9 billion pairs of gloves ( 61.8 billion pieces) which is then increased to 44.4 billion pairs ( 88.8 billion pieces) in 2016 (LGM, 2016), it even reached 228 billion pieces in 2017. With sales value of RM 8.5 million in 2011, RM 10.4 billion in 2015, and RM 15.9 million in 2017, Malaysia's gloves market share is targeted to reach $65 \%$ by 2020 , while Indonesia's share is expected to only be around 3-5\%. Therefore, it can be concluded that Indonesia's rubber gloves industry is far behind compared to Malaysia.

Malaysia's natural rubber industry is managed by the Malaysian Rubber Board (MRB). The goal of the industrial development is very clear, namely to achieve a foreign exchange target of RM 54 Billion by 2020, with a composition of $51 \%$ rubber products, $18 \%$ natural rubber, $21 \%$ rubber wood products, and $10 \%$ other products. Moreover, Malaysia's National rubber industry strategies for 2015-2020 are: (1) economic transformation program, (2) 11th Malaysian plan, (3) one national strategy. The innovations are developed so that Malaysia will become the leader in technology, environmental conservation and sustainability. This is achieved through an innovation system, which includes the relationship and cooperation between MRB and university, industry, collaborative innovative supplier and rival innovative enterprise (Nor, 2017). Therefore, it can be said that Malaysia has a very good innovation capacity which cause the industry to grow rapidly. Based on the elaboration above, the questions of why the latex-based natural rubber industry in Indonesia is still lagging behind Malaysia, what factors that cause this to happen (in relation to its ability to innovate), and what to be done to improve Indonesia's industry competitiveness arise. The objective of this study is to measure Indonesia's innovation capacity in the latex-based natural rubber industry compared to Malaysia.

\section{Methodology}

2.1 Research Framework

This research begins with gathering information about measurement standards, and determining innovation capacity indicators or dimensions through literature review. In determining the measurement standards and innovation capacity dimensions this study refers to the method developed by National Innovation Agency and King Mongkut's University of Technology Thonburi (Wonglimpiyarat, 2010). The method consists of 5 (five) dimensions, which include: (1) Organizational innovation capability, (2) Process innovation capability, (3) Service innovation capability, (4) Product/product development innovation capability, and (5) Marketing innovation capability. After determining the dimensions, the study then proceed with in depth interviews and focus group discussion (FGD) to determine the attributes of each dimension. The next step is questionnaire creation and distribution to be filled out by selected expert respondents (purposed sampling method). Data from the questionnaire is then processed using RAPFISH software, which in this case will be called RAPIC-NRI (Rapid Appraisal Innovation Capacity of Natural Rubber Industry). The overall research process flow can be seen in Figure 1. 


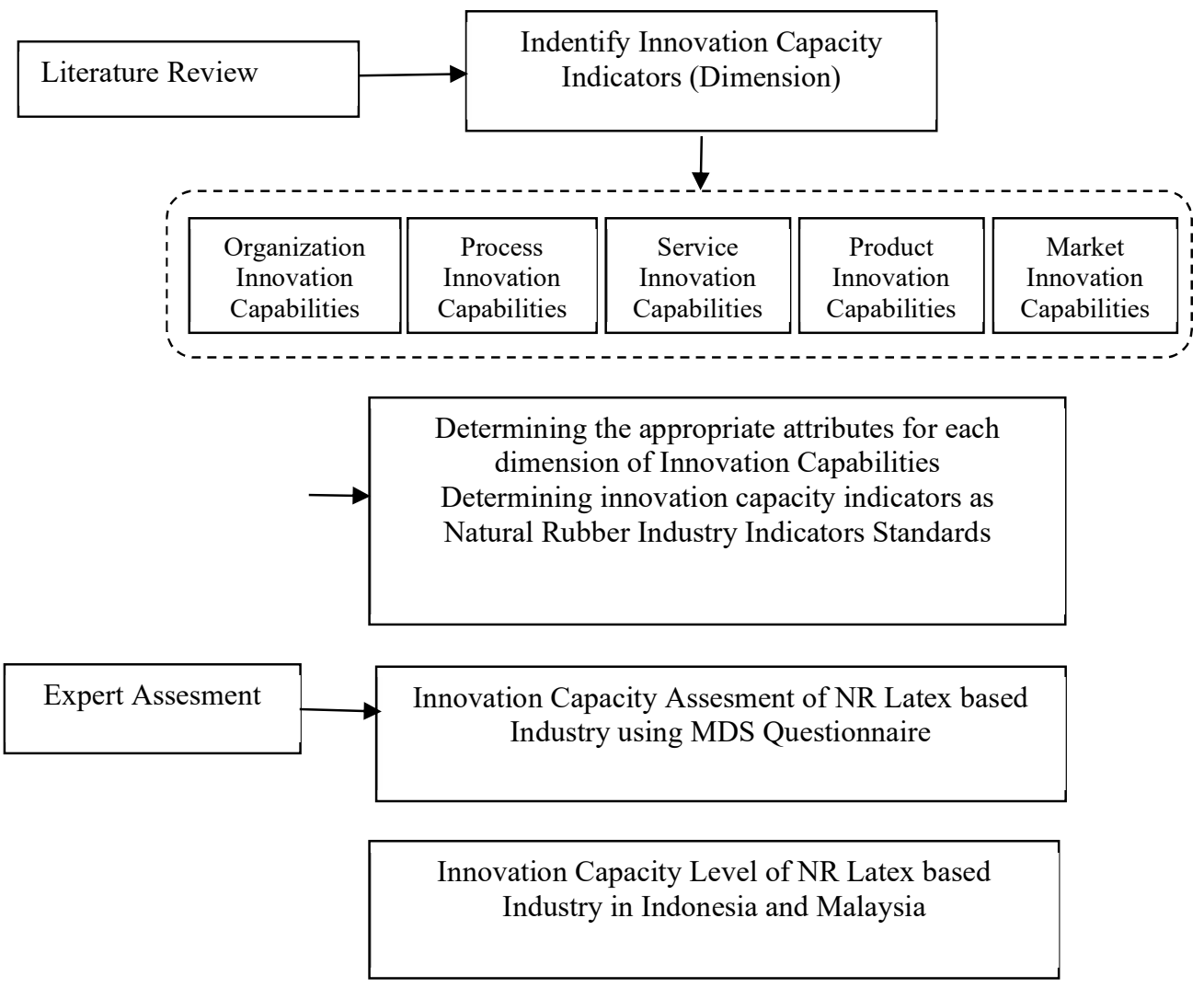

Figure 1. Research Framework

\subsection{Attribute and Data Requirement}

Attributes determination for each dimension, namely the organization, process, service, product/product development and marketing dimension is done through a literature review, which is then validated, corrected and approved by the experts.

2.2.1 Dimension 1: Organizational Innovation Capability (OIC)

OIC refers to organizational capability to accept new things, and its availability in facilitating new technology to employees (Wonglimpiyarat, 2010). This is closely related to the leadership, climate, culture and values that are adhered to in the organization and highly dependent on human resources, skills and competencies (Suominen and Jussila, 2013). Structural, personnel, and operational capabilities are important components of organizational innovation capabilities (Momeni, 2015). In addition, organizational empowerment which is related to innovation competence is largely determined by: (1) absorption, (2) constructive feedback, (3) challenges, (4) ability to change, (5) communication, (6) flexibility, (7) freedom, (8) empowerment, (9) stress management, (10) variations needed, (11) learning support organizations, (12) networks, (13) risk resistance, (14) development support organizations, (15) information seekers, (16) teamworks and collaboration, (17) trust and tolerant, and (18) idea generation.

Based on the literature review and experts validation, it was agreed upon that 7 (seven) attributes to the organizational innovation capability dimension are:

(1) Leadership that supports policies for the innovation creation in an organization (OIC1);

(2) The ability to create climate, culture and values that support innovation in an organization (OIC2);

(3) The ability to maximize the empowerment of available resources within the organization (OIC3);

(4) Opportunity to accept new initiatives or for idea generation (organization that is open to changes and new ideas) (OIC4);

(5) Organizations that are communicative and are supportive in learning (effective organizations) (OIC5);

(6) The ability to construct and develop teamwork, network, and collaboration (OIC6); and

(7) Resilient in overcoming obstacles and risks (OIC7).

\subsubsection{Dimension 2: Process Innovation Capability (PIC)}

PIC refers to organizational capability to adjust processes at all levels, including production process, inventory distribution, logistics, and additional supporting activities such as accounting, purchasing and finance (Wonglimpiyarat, 2010). Thus, process innovation capability focuses on the issue regarding resources for the 
production process, procedures and production process knowledge (Ortiz et al., 2017). Costs, quality, flexibility, speed and consistency of production can be controlled by technologies, methods and techniques in the production process.

Based on the literature review and experts validation, it was agreed upon that 4 (four) attributes to the process innovation capability dimension are:

(1) The ability to plan and change the production process in accordance to market developments and technological trends (PIC1);

(2) The ability to provide materials and equipment for the production, distribution and logistical process (PIC2);

(3) The ability to assess the performance of on going processes (PIC3); and

(4) The ability to utilize supporting functions (purchasing, accounting, finance) and artificial intelligence so that the process runs efficiently (PIC4).

2.2.3 Dimension 3: Service Innovation Capability (SIC)

SIC refers to organizational capability to apply new technology and knowledge in order to develop new ways of service to significantly improve production process, and deliveries of goods or services (Wonglimpiyarat, 2010). Customers' satisfaction is the goal of service innovation. This can be achieved by mapping the gap between real services and consumer expectations, followed by finding solutions and developing new services, which are commonly known as Sensing-Seizing-Transformation (Popperbub et al., 2014). Sensing is done through scanningevaluating and detailing. While, seizing is done through solution development-solution evaluation and selectionsolution detailing. And, transformation is done through unfreezing-changing and freezing. In line with Popperbub, Linduhlt (2013), the service innovation capability can be done through 6 stages: (1) Sensing user needs and technological options (2) Conceptualization, (3) bundling and unbundling, (4) Coproducing and orchestrating, (5) Scaling and stretching, (6) Learning and adapting.

Based on the literature review and experts validation, it was agreed upon that 4 (four) attributes to service innovation capability are:

(1) The ability to identify consumer needs in relation to service provision (SIC1);

(2) The ability to evaluate services (SIC2);

(3) The ability to develop solutions and transform into the latest form of services (SIC3); and

(4) The ability to provide after sales services to maintain customers' loyalty and satisfaction (SCI4).

2.2.4 Dimension 4: Product/Product Development Innovation Capability (DIC)

DIC refers to organizational capability in applying new technology and knowledge to develop new product innovations, in order to increase revenue at all levels (Wonglimpiyarat, 2010). In addition, Adler an Shenbar (1990) stated that the product/product development innovation capability refers to the organization's capacity to develop and adjust new products to meet market needs. Accoring to Vorhies (2002) product/product development innovation capability is obtained through market and technical knowledge which is created to produce new products that are valuable both from outside and within the organization.

Knowledge and learning process have important role in developing innovative products ( $\mathrm{Li}$ and Calantone, 1998; Madhavan and Goner, 1998; Moorman and Miner, 1997), while the role of technical knowledge/capabilities and market knowledge is crucial (Vorhies, 2002). Technological capability in relation to competitive and innovative products is highly dependent on the organization's strategic capabilities, sources of knowledge, fundamental R\&D, applied R\&D and manufacturing capabilities (Li jun and Juhua, 2016).

Based on the literature review and experts validation, it was agreed upon that 5 (five) attributes to product/product development innovation capability are:

(1) The ability to carry out an accurate analysis of market needs (DIC1);

(2) The ability to implement existing knowledge to create new innovative products (DIC2);

(3) The ability to assess product performance and determine the optimal performance adequacy measures to meet market needs (DIC3);

(4) The ability to produce innovative products and achieve economies of scale (DIC4);

(5) The ability to maintain quality consistency in accordance to the innovation specifications (DIC5). 2.2.5 Dimension 5: Marketing Innovation Capability (MIC)

MIC refers to organizational capability to implement new technology or improvement of company's products and operational marketing processes (Wonglimpiyarat, 2010). According to Ngamsutti and Ussahawanitchakit (2016), marketing innovation capability is a way of using innovation or significant improvements in marketing methods that will greatly affect the company in terms of product design, packaging, placement, promotion and pricing. This issue depends on innovativeness, innovation capacity and willingness to change. Moreover, marketing innovation capability highly depends on strong consumer relationships as well as the extent of network connectivity. Marketing capabilities are grouped as Outside-in capabilities, Inside-out capabilities, spanning capabilities (Day, 1994) and Networking capability (Rostami, 2015).

Based on the literature review and experts validation, it was agreed upon that 5 (five) attributes to service 
innovation capability marketing innovation capability are:

(1) The ability to convince potential customers that the product innovation can substitute, provide benefits and is needed by consumers (MIC1);

(2) The ability to drive company resources to become customer-oriented (MIC2);

(3) The ability to build effective strategic networks with customers (MIC3);

(4) The ability to use new lines of communication (internet, social media) that are more effective and efficient (MIC4); and

(5) The ability to identify changes in consumer habits and make adjustments to marketing strategies accordingly (MIC5).

\subsection{Multidimensional Scaling (MDS) Method}

MDS is statistical analysis used to identify and visualize the similarities and dissimilarities between variables depicted in geometric space (Kruskal, 1977; Borg and Groenen, 2005). Stages in using MDS method are determination of dimensions and attributes through expert discussion followed by ordinal assessment and scoring in the range of 1 (low) to 4 (very high) according to attributes characteristics of the selected respondents. The questionnaire is in the form of choice on an ordinal scale from 1 (low) to 4 (very high). The range of scores for the innovation capability measurement is presented in Table 1.

Table 1. Scores range to measure the level of innovation capability performance

\begin{tabular}{|c|c|}
\hline Range of score & Innovation capability performance level \\
\hline $1.00-1.75$ & Low \\
\hline $1.76-2.50$ & Medium \\
\hline $2.51-3.25$ & High \\
\hline $3.26-4.00$ & Highest \\
\hline
\end{tabular}

Source: Research report of Thailand innovation capability index (National Innovation Agency and King Mangkut's University of Technology Thonbury (Wonglimpiyarat 2010)

The next steps in carrying out the MDS are ordination, leveraging and performing the Monte-Carlo Analysis (Fauzi, 2019). Ordination is placed in a two-dimensional curve, where only the horizontal dimension (x-axis) has significance in ordination. In principle, leveraging detects the dominant attribute. Its values range from $2 \%$ to $6 \%$ and are measured by Root Mean Square (RMS). Finally, Monte-Carlo Analysis is carried out to detect the source of errors (errors).

\subsection{Respondent of Research}

In this study, a survey is conducted in the form of questionnaire which then will be filled out by experts. The selected respondents are truly experts in their fields, thus they will provide expert judgments which take into account the aspect of government, R\&D institutions, industry, capital institutions and associations. The number and composition of respondents are shown in Table 2.

Table 2. The number and profession of each respondent

\begin{tabular}{|c|c|c|}
\hline \multirow{2}{*}{ Profession } & \multicolumn{2}{|c|}{ Number of experts } \\
\cline { 2 - 3 } & In-depth Interviews & MDS Questionnaire \\
\hline Government Officials & 6 & 3 \\
\hline Company (Industry) & 5 & 3 \\
\hline Association Members & 4 & 3 \\
\hline R\&D Institutions & 4 & 4 \\
\hline Financial institutions & 1 & 1 \\
\hline Total & 20 & 14 \\
\hline
\end{tabular}

\section{Results and Discussion}

3.1 Results of Capacity Analysis and Capacity Innovation Index

The results from RAPIC-NRI are presented in Table 3. The average of Indonesia's latex-based natural rubber industry innovation capacity index is 60.22 , while it is 78.80 for Malaysia. This shows that the industrial innovation capacity in Indonesia is still lower than Malaysia. In addition, when viewed in more detail, Indonesia's position for the organizational, processes, services, product/product development and marketing innovation capabilities are still lower than Malaysia (Figure 2). 
Table 3. Comparison of the average innovation capacity and innovation capacity index between Indonesia and Malaysia

\begin{tabular}{|c|c|c|c|c|c|c|c|}
\hline Dimension & \multicolumn{2}{|c|}{ Average Value of Innovation Capability } & \multicolumn{3}{c|}{ Innovation Capacity Index } \\
\hline & \multicolumn{2}{|c|}{ Indonesia } & \multicolumn{2}{c|}{ Malaysia } & Indonesia & Malaysia & GAP \\
\hline$(1)$ & \multicolumn{2}{|c|}{$(2)$} & \multicolumn{2}{|c|}{$(3)$} & $(4)$ & $(5)$ & $(6)$ \\
\hline OIC & 2.07 & Medium & 3.04 & High & 68.00 & 83.49 & -15.49 \\
\hline PIC & 1.85 & Medium & 2.75 & High & 59.25 & 75.00 & -15.75 \\
\hline SIC & 1.88 & Medium & 2.94 & High & 55.00 & 80.86 & -25.86 \\
\hline DIC & 1.86 & Medium & 3.05 & High & 57.37 & 79.63 & -22.26 \\
\hline MIC & 1.96 & Medium & 2.75 & High & 61.46 & 75.00 & -13.54 \\
\hline Total & 1.94 & Medium & 2.92 & High & 60.22 & 78.80 & -18.58 \\
\hline
\end{tabular}

$\mathrm{OIC}$

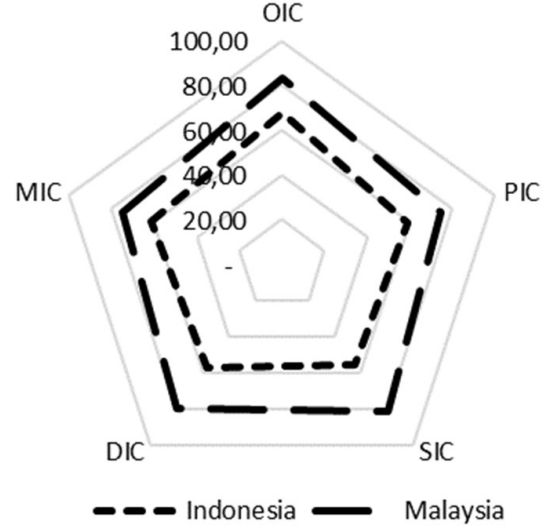

Figure 2. Comparison of Innovation Capability Indexes for Each Dimension 3.1.1 Organizational Innovation Capability

The average score for Indonesia's organizational innovation capability is 2.07 (moderate) with an index value of 68.00. While the average score for Malaysia is 3.04 (high) with an index value of 83.49 (Table 3). The comparison of the average organizational innovation capability values for each attribute is presented in Figure 3.

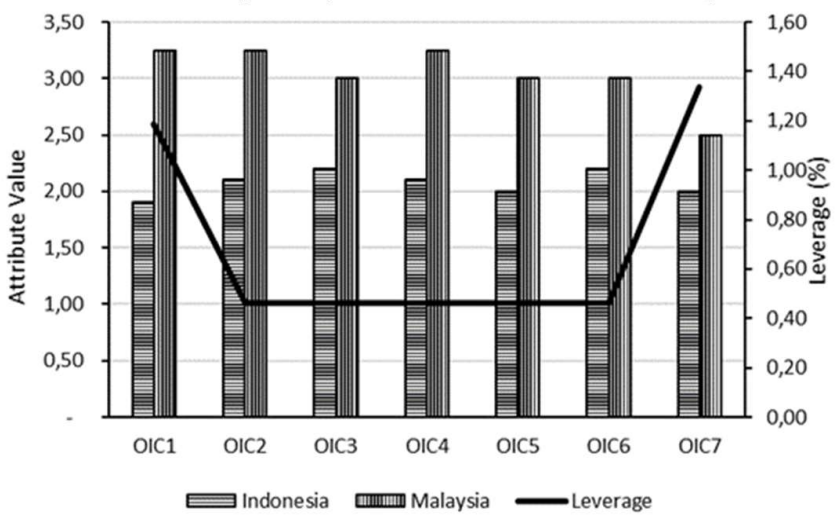

Figure 3. Comparison of The Average Organizational Innovation Capability Index and Sensitive Factor Affecting Organizational Innovation Capability Dimension (Leverage) for Each Attribute Between Indonesia and Malaysia

From the seven attributes of the organizational capability dimension, Malaysia holds the advantage of all attributes. The most important attribute is the leadership that supports policies for the innovation creation in an organization, while this attribute has the lowest score for Indonesia (OIC1). Another attributes with a high score are the ability to create climate, culture and values that support innovation in an organization (OIC2), as well as the opportunity to accept new initiatives (idea generation) (OIC4). The other three attributes that hold important role and cause Malaysia to be more superior to Indonesia, are the ability to maximize the empowerment of available resources within the organization (OIC3), organizations that are communicative and are supportive in learning (OIC5), and the ability to construct and develop teamwork, network, and collaboration (OIC6). Moreover, despite having a lower average score, for resilient in overcoming obstacles and risks (OIC7) Malaysia is still superior to Indonesia. 


\subsubsection{Process Innovation Capability}

The average score for Indonesia's process innovation capability is 1.85 (moderate) with an index value of 59.25. While the average score for Malaysia is 2.75 (high) with an index value of 75.00 (Table 3). Comparison of the average process innovation capability index (Figure 4) shows that of the four attributes, which are the ability to plan and change the production process in accordance to market developments and technological trends (PIC1), the ability to provide materials and equipment for the production, distribution and logistical process (PIC2), the ability to assess the performance of ongoing processes (PIC3), and ability to utilize supporting functions (purchasing, accounting, finance) and artificial intelligence so that the process runs efficiently (PIC4), Malaysia performs better than Indonesia.

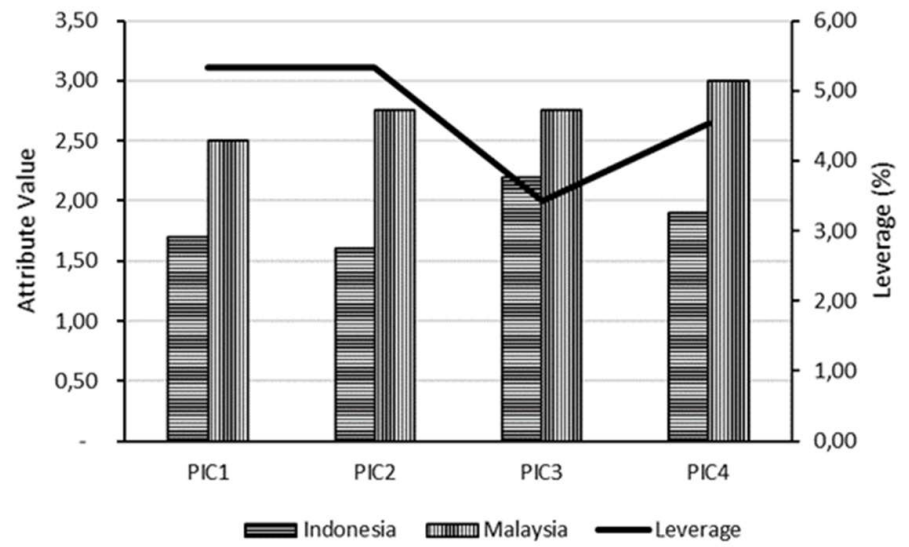

Figure 4. Comparison of The Average Process Innovation Capability Index and Sensitive Factor Affecting

Process Innovation Capability Dimension (Leverage) for Each Attribute Between Indonesia and Malaysia 3.1.3 Service Innovation Capability

The average score for Indonesia's service innovation capability is 1.88 (moderate) with an index value of 55.00 . While the average score for Malaysia is 2.94 (high) with an index value of 80.86 (Table 3). Comparison of the average service innovation capability index (Figure 5) shows that of the four attributes, which are the ability to identify consumer needs in relation to service provision (SIC1), the ability to evaluate services (SIC2), the ability to develop solutions and transform into the latest form of services (SIC3), and the ability to provide after sales services to maintain customers' loyalty and satisfaction (SIC4), Malaysia is superior to Indonesia.

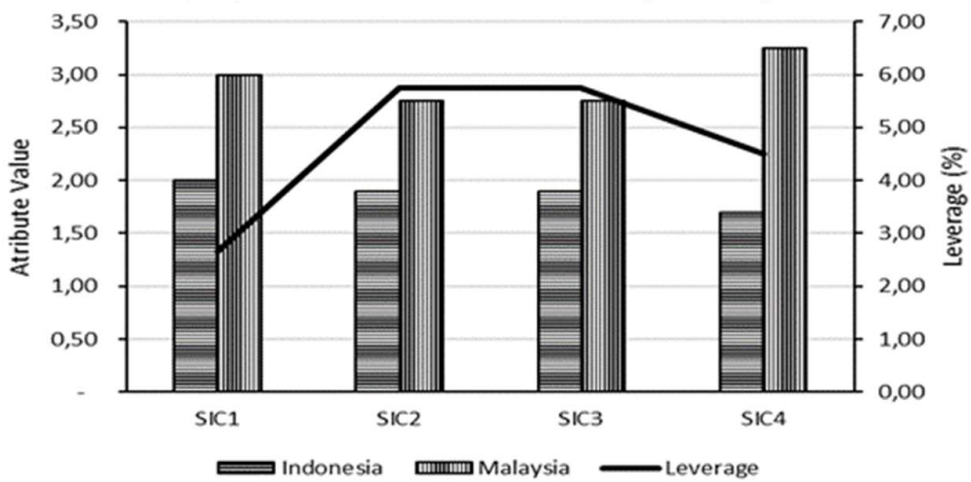

Figure 5. Comparison of The Average Service Innovation Capability Index and Sensitive Factor Affecting

Service Innovation Capability Dimension (Leverage) for Each Attribute Between Indonesia and Malaysia

\subsubsection{Product/ Product Development Innovation}

The average score for Indonesia's product/product development innovation capability is 1.86 (moderate) with an index value of 57.37. While the average score for Malaysia is 3.05 (high) with an index value of 79.63 (Table 3). Comparison of the average product/product development innovation capability (Figure 6) shows that of the five attributes which are, the ability to carry out an accurate analysis of market needs (DIC1), the ability to implement existing knowledge to create new innovative products (DIC2), the ability to assess product performance and determine the optimal performance adequacy measures to meet market needs (DIC3), the ability to produce innovative products and achieve economies of scale (DIC4), and the ability to maintain quality consistency in accordance to the innovation specifications (DIC5), Malaysia is superior to Indonesia. 


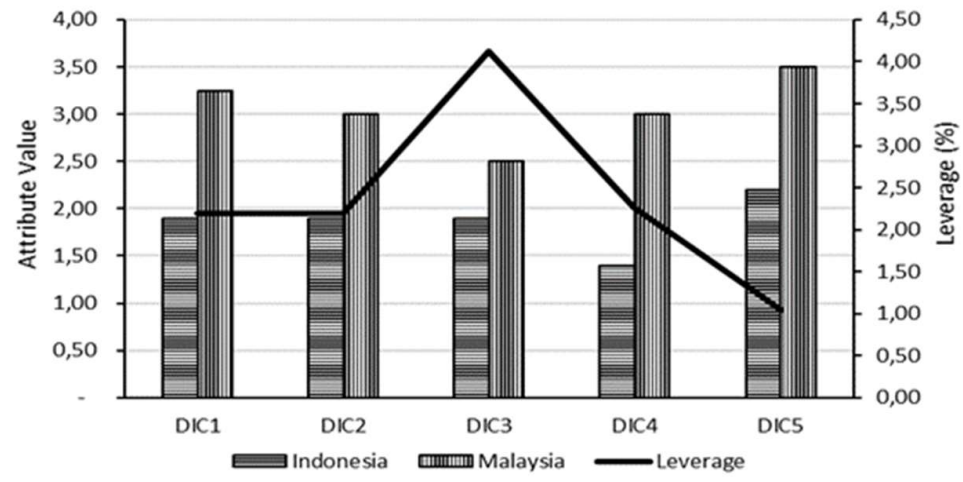

Figure 6. Comparison of The Average Product/Product Development Innovation Capability Index and Sensitive Factor Affecting Product/Product Development Innovation Capability Dimension (Leverage) for Each Attribute

\subsubsection{Marketing Innovation Capability}

Between Indonesia and Malaysia

The average score for Indonesia's marketing innovation capability is 1.96 (moderate) with an index value of 61.46 . While the average score for Malaysia is 2.75 (high) with an index value of 75.00 (Table 3). Comparison of the average marketing innovation capability (Figure 7) shows that of the five attributes, which are the ability to convince potential customers that the product innovation can substitute, provide benefits and is needed by consumers (MIC1), the ability to drive company resources to become customer-oriented (MIC2), the ability to build effective strategic networks with customers (MIC3), the ability to use new lines of communication (internet, social media) that are more effective and efficient (MIC4) and the ability to identify changes in consumer habits and make adjustments to marketing strategies accordingly (MIC5), Malaysia is still superior to Indonesia.

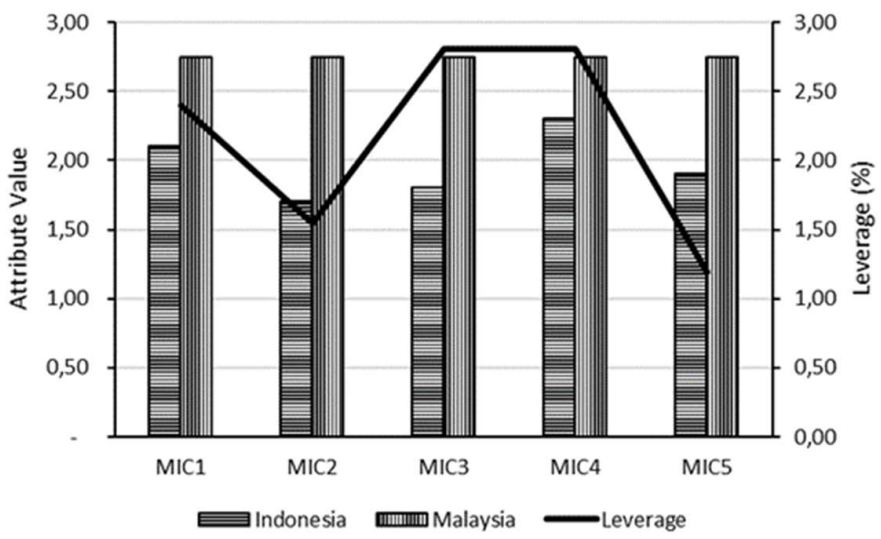

Figure 7. Comparison of The Average Marketing Innovation Capability Index and Sensitive Factor Affecting Marketing Innovation Capability Dimension (Leverage) for Each Attribute Between Indonesia and Malaysia 3.1.6 Validation of Innovation Capability Index Assessment

The error and diversity of the attribute scores is tested by performing the monte carlo analysis (Fauzi, 2019), with a 95\% confidence interval. The comparisons of MDs calculation results for each dimension of innovation capacity using the monte carlo method are presented in Table 4. The error value for each dimension, both for Indonesia (INA) and Malaysia (MY), is at the level of $<5 \%$ or it can be said that the accuracies of the calculation and analysis are good. 
Table 4. MDs and Monte-carlo analysis results Capacity Innovation index of the latex-based natural rubber industry with a $95 \%$ confidence interval

\begin{tabular}{|c|c|c|c|c|c|c|c|c|}
\hline Dimension & \multicolumn{2}{|c|}{ MDS(\%) } & \multicolumn{2}{c|}{ Monte-carlo (\%) } & \multicolumn{2}{c|}{ Error (\%) } & \multicolumn{2}{c|}{ Notes } \\
\hline & INA & MY & INA & MY & INA & MY & INA & MY \\
\hline OIC & 86.00 & 83.49 & 71.22 & 84.33 & 3.22 & 0.84 & Valid & Valid \\
\hline PIC & 59.25 & 75.00 & 57.50 & 72.20 & 1.76 & 2.80 & Valid & Valid \\
\hline SIC & 55.00 & 80.86 & 58.25 & 83.17 & 3.25 & 2.32 & Valid & Valid \\
\hline DIC & 57.37 & 79.63 & 59.84 & 82.22 & 2.47 & 2.58 & Valid & Valid \\
\hline MIC & 61.46 & 75.00 & 61.79 & 78.56 & 0.33 & 3.56 & Valid & Valid \\
\hline
\end{tabular}

\subsection{Discussion}

Out of the 25 (twenty-five) attributes of each dimension of innovation capability (organizational, process, service, product/product development and marketing) Malaysia's latex-based natural rubber industry is superior to Indonesia.

One important factor that determines organizational capability is the ability to foster a high innovation and learning spirit within an organization (Ulrich and Smallwood, 2007). This ability depends on internal and external factors of the organization. The internal factors include leadership, climate, culture and values that are adhered to in the organization and highly dependent on human resources, skills and competencies (Suominen and Jussila, 2013). According to Siyamtinah et al. (2011), other internal factors such as research and development support, compatibility of employees' abilities and expertise, training and development of human resources, and the availability of new machinery and technology also greatly contribute to the organizational innovation capability. While the external factors that influence the organizational innovation capabilities are the interaction and communication with consumers, suppliers, competitors, external R\&D institutions, and industry associations (Romijn et al., 1999), along with the supports from government and financial institution (Siyamtinah et al., 2011).

The size of the organization and its time dimension (organization's age) are also influential in maintaining the innovation stability. A study by Baldwin et al. (2000) found that big companies are more innovative than small companies, since they have easier access to funds, economic of scope as well as comprehensive R\&D segment. On the contrary, Baldwin (1995) found that more intensive innovation activities occurring in small to mediumsized companies in Canada. This is due to the fact that small organizations are leaner organizations with fast decision-making process and close relationship between consumers and suppliers.

Companies that are operating in the latex-based rubber industry in Malaysia such as Top Glove, Kossan, Supermax, Hertalega and Riverstone are listed in Singapore Stock Exchange. These are large and public companies that have easy access to financial institutions, excellent marketing networks, and R\&D departments. Malaysian government supports are also very adequate. Tun Abdul Razak Research Centre (TARRC), which is founded in London (1938) is the research and promotion center for Malaysian Rubber Board (MRB). The research center's main mission is to improve Malaysia's rubber industry competitiveness and sustainability in the global environment through $R \& D$, transfer of technology and service as well as effective quality support. These are Malaysia's advantages over Indonesia.

Process innovation capability is an organization's capability to acquire, assimilate, change, and exploit resources, procedures, and technical related knowledge for the purpose of innovation process, as it is the organization's capability to produce innovation in the production process (Peris et al., 2017). Moreover, organizations' operational processes including concurrency process, formality process, and adaptability process are dependent on technological input. The outputs of the innovation are good products quality, cost-per-unit efficiency and product speed in entering the market. (Tatikonda and Weiss, 2001). Malaysia's strategy to reduce production costs to increase the export prices competitiveness by encouraging investment abroad. Through Malaysian Industrial Development Authority (MIDA), Malaysia promotes and supports investment abroad in order to get cheaper and more affordable raw materials. The investment cooperation agreement is carried out with other ASEAN countries, who produce rubber raw materials with lower production costs (Syarifa, 2011).

Service innovation refers to development of services that are considered as new and beneficial to consumers (Flint et al., 2005; Grant, 1991). Organization can increase its value by improving its services. Service-based competition is one of the best ways to generate value, for example, logistics services provide a competitive advantage for companies since it provides greater speed, reliability, flexibility, and cost effectiveness in the distribution channel (Daugherty et al., 1998; Sahin et al., 2007). Service innovation is often associated with the creation of customer value that is constantly changing. Consequently, creating value through service innovation often requires companies to anticipate customer's future needs. For orginzation to offer complete value to customers, they need to anticipate changes in the environment as they develop new services (Kandampully, 2002). Malaysia is more advance in terms of service innovations compared to Indonesia. Especially with the support of various organizations and associations formed by the Malaysian government. This is very helpful for Malaysian companies in responding to changes in consumer needs and demand for both product and service quality. 
As the major latex products producer in the world, Malaysia has made various efforts to introduce its product brands and expand its export market. The government has promoted Standard Malaysian Glove (SMG) so that its latex glove products become internationally recognized and accepted. Glove-producing companies have been encouraged to obtain Standard Malaysian Glove (SMG) certification to ensure the quality and reliability of the products. Research and development activities are also enhanced further to ensure that Malaysian latex products meet the international standards in terms of health and safety (Syarifa, 2011). In addition, research and development also focuses on product diversification, manufacturing technology improvement and increasing product value addition (Ministry of International Trade and Industry, 2006).

In relation to its marketing innovation, Malaysia has expanded its export market through trade promotion activities that are carried out comprehensively and in a coordinated manner by government agencies such as Malaysian External Trade Development Corporation (MATRADE), The Ministry of Plantation Industries and Commodities (MPIC), Malaysia Rubber Board (MRB) and Malaysian Rubber Export Promotion Council (MREPC) (Syarifa, 2011). In addition, international exhibitions are carried out by MATRADE and TARRC (Tun Abdul Razak Research Centre). New export markets, such as Latin America, Africa, West and Central Asia, have become important export potential for the Malaysian latex finished goods industry.

There are several reasons of why Indonesia's innovation capacity still lags behind Malaysia. These include factors such as regulatory and policy, institutional, capital support, human resource competencies, technology, infrastructure and marketing issues. Support from the government and capital institutions, strong innovation institution and the existence of legal and regulatory protection (such as innovation law) are key factors in improving the innovation-based industry competitiveness in Indonesia.

\subsection{Managerial Implications}

Increase in the Indonesia's latex-based natural rubber downstream industry innovation capacity through enhancement of organizational, processes, services, products and marketing innovation capability are essential to improve the industry competitiveness. Moreover, supports from various stakeholders such as government, R\&D institutions, universities, industry players, financial institutions and the community are needed. The role of government political commitment is vital, especially in relation to the legal certainty and protection, institutions, infrastructure, human resource development and easy access to capital. The lack of coordination between institutions that has occurred so far can be strengthened through utilization and restructuration of existing institutions. Lastly, institutions that are still private agencies can be reformed to become legitimate government institutions that have legal power as a government agency, such as the formation of the Indonesia Rubber Board.

\section{Conclusion and Recommendation}

Indonesia's latex-based natural rubber industry innovation capacity still lags behind when compared to Malaysia. The average Indonesia's innovation capacity index is 60.22 , while it is 78.80 for Malaysia. Based on the five capability dimensions, namely organizational, process, service, product/product development, and marketing innovation capabilities, Malaysia is still superior to Indonesia. Moreover, Malaysia holds advantages in all innovation capabilities attributes compared to Indonesia. The government supports in relation to legal certainty and protection, institutional strengthening, human resources, easy access to capital as well as cooperation between various stakeholders are the key factors in increasing the innovation capacity in order to improve Indonesia's industry competitiveness.

\section{References}

Adler, P. S. and Shenbar, A. (1990). "Adapting your technological base: The organizational challenge". Sloan Management Review. 25: 25-37.

Baldwin BG et al. (1995). "The ITS Region of Nuclear Ribosomal DNA: A Valuable Sources of Evidence on Angiospermae Phylogeny”. Ann.Missouri Bot. Gard. 82:247-277.

Baldwin, John R.Hanel, Peter, and Sabourin, David. (2000). "Departments of Innovative Activity in Canadian Manufacturing Firm: The Role of Intellectual Property Right”. Research Paper Series, Statistics Canada. No. 11F0019 MPE No. 122.

Borg, I., Groenen, P. (2005). “Modern Multidimensional Scaling: Theory and Application” (2 ${ }^{\text {nd }}$ ed), New York: Springer-Verlag, pp. 207-212.

Daugerty, PJ., Stank, T.P., dan Ellinger, A. E. (1998). "Leveranging Logistics/ distribution capabilities: The Impact of Logistics Servise on Marker Share". Jurnal of Businnes Logistics. 19 (2).

Day, G,S. (1994). “The Capabilities of Market-Driven Organization”. Journal Of Marketing. 58 (4) hlm. 37-52

Dekarindo. (2017). "Data Statistik Industri Karet Indonesia". Jakarta (ID): Dewan Karet Indonesia

Dekarindo. (2019). “Data Statistik Industri Karet Indonesia”. Jakarta (ID): Dewan Karet Indonesia

Departemen Perindustrian. (2009). "Peta Panduan (Road Map) Pengembangan Kluster Industri Prioritas: Industri berbasis Agro Tahun 2010-2014”. Jakarta (ID): Departemen Perindustrian Jakarta. 
Direktorat Jenderal Perkebunan. (2017). "Statistik Perkebunan, Komoditi Karet”. Jakarta (ID): Dirjenbun

Erni Nofi. (2013). "Usulan Strategi Pengembangan Industri Karet alam Indonesia”. Jurnal Inovasi. 9(2):70-78.

Flint, D.J., Larsson, E., Gammelgaard, B. and Mentzer, J.T. (2005). "Logistics innovation: a customer valueoriented social process". Journal of Business Logistics. 26(1):113-147.

Fauzi RI. (2013). “Alternatif Strategi pengembangan Industri Barang jadi karet Indonesia”. Warta Perkaretan. 32 (2):55-64.

Fauzi Akhmad. (2019). “Teknik Analisis Keberlanjutan”. Jakarta (ID): PT. Gramedia Pustaka Utama.

Gapkindo. (2016). "Statistik Karet Indonesia”. Jakarta (ID): Gapkindo

Gapkindo. (2019). "Statistik Karet Indonesia". Jakarta (ID): Gapkindo

Grant, R.M. (1991). "The resource-based theory of competitive advantage: implications for strategic formation". California Management Review. 33 (3):114-135.

International Rubber Study Group. (2019). "Rubber Statistic Buletin”. Singapore (SG): IRSG. 73: 10-12

Kandampully, K. (2002). "Elektronik Ritel dan Perantara distribusi Layanan Yang Melayani Pelanggan dan Penyedia Layanan”. Journal of Management and Strategy, 3.

Kandampully, J. (2002). "Innovation as the core competency of a service organisation: the role of technology, knowledge and networks". European Journal of Innovation management. 5(1): 18-26. [Online] Available: https://doi.org/10.1108/14601060210415144

Kavanagh, P., Pitcher, T.J. (2004). "Implementing Microsoft Excel Software for Rapfish: Technique for the Rapid Appraisal of Fisheries (Rapfish) Status". Vancouver (CA): Fisheries Centre, University of British Columbia. Columbia. [Online] Available: https://doi.org/10.14288/1.0074801.

Kruskal, J.B., Wish, M. (1977). "Multidimensional Scaling”. USA: Sage Publications, Beverly Hills.

Lembaga Getah Malaysia. (2016). "Natural Rubber Statistics 2016”. Malaysia. [Online] Available: http://www.lgm.gov.my/nrstat/nrstats2016 (Jan-Dec) pword.pdf

Lembaga Getah Malaysia. (2019). "Natural Rubber Statistics 2019”. Malaysia.

Li, Tiger, Calantone, Roger J. (1998). "The Impact of Market Knowledge Competence on New Product Advantage: Conzeptualization and Empirical Examination. Journal of Marketing”, Vol.62, p. 13-29.

Lindhult E. (2013). "Service Innovation Capabilities in Large Industrial Company. The XXIV ISPIM Conference - Innovating in Global Markets: Challenges for Sustainable Growth in Helsinki, Finland" [Online] Available: 16-19 June 2013. pp 1-9 (The publication is available to ISPIM members at www.ispim.org.)]

Momeni, Mostafa, Nielsen, Susanne Balslev, dan Kafash, Mahdi Haghighi. (2015). "Determination of Innovation Capability of Organizations: Qualitative Meta Synthesis and Delphi Method". RESER2015 - Innovative Services in the 21 $1^{\text {st }}$-25th conference, 10-12. September 2015, Denmark

Moorman C and Miner S A. (1997). "The Impact of Organizational Memory on New Product Performance and Creativity”. Journal Marketing Research. 34(1):91-106. https://doi.org/10.1177/002224379703400108

Ngamsutti S and Ussahawanitchakit. (2016). "Marketing innovation capability and marketing performance: an empirical study of electrical and electronic appliances in Thailand". The Business and Management Review. 7(5): 339-346.

Nor ZM. (2017). "Positioning R and D to Respond to Challenges and Opportunities of Desruptive Technologies". Global Rubber Confrence. Kuala Lumpur (ML).

Ortiz M M, Caranana D C, Armengot R C. (2017). "Process Innovation Capability. E. E.G. Carayannis (ed.), Encyclopedia of Creativity, Invention, Innovation and Entrepreneurship, Springer Science Business Media LLC 2017”. Doi: 10.1007/978-1-4614-6616-1_200022-1

Peris-Ortiz M., Devece Carañana C., Rueda-Armengot C. (2017). "Process Innovation Capability. In: Carayannis E. (eds) Encyclopedia of Creativity, Invention, Innovation and Entrepreneurship”. New York,: Springer

Poppelbub J, Plattfaut R, Ortbach K, Malsbender A, Voigt M, Niehaves B, Becker J. (2014). "Service Innovation Capability: Proposing a New Framework. Proceedings of the Federated Conference on Computer Science and Information System". SZCZECIN. $2011:$ 545-551.

[RPN] Riset Perkebunan Nusantara. (2011). "Pra Studi Kelayakan Pembangunan Industri Sarung Tangan dan Benang Karet PT. Perkebunan Nusantara VIII (Persero) RPN". Bogor (ID): RPN

Romjin, Henny, Albaladejo, Manuel. (1999). "Determinants of Innovation Capability in Small UK Firms: An Empirycal Analysis. QEH Working Paper Series”, 40.

Rostami, Najibeh Abbasi. (2015). "Examining the Relationship between Marketing Capability and Innovation. International Journal of Management, Accounting and Economics". 2(1) :ISSN 2383-2126.

Sahin, E., Babai, M.Z., Dallery, Y. and Vaillant, R. (2007). "Ensuring supply chain safety through time temperature integrators. International Journal of Logistics Management". 18 (1): 102-124.

Siyamtinah, Heru Sulistyo dan Eny Rahmani. (2011). "Model Peningkatan Kinerja melalui Kapabilitas Inovasi pada UKM di Kota Semarang”. Makalah Seminar Nasional Ilmu Ekonomi Terapan Fakultas Ekonomi UNIMUS 2011.

Suominen A and Jussila J. (2015). “Organizational Innocation Capability. In book: Building Blocks of Agile 
Innovation". Publisher: Book Surge Publishing. Editors: Nilay Oza, Pekka Abrahamsson. doi: 10.13140/RG.2.1.4823.4088

Syarifa F L. (2011). "Permintaan Ekspor Sarung Tangan Lateks Malaysia”. Jurnal penelitian Karet. 29 (1) : 151 158.

Ulrich, D and Smallwood, N. (2007). "Leadership Brand: Developing customer-focused leaders to drive performance and build lasting value". Boston: Harvard Business School Press.

Vorhies, Douglas W, Im Subin, Morgan, Neil A. (2002). "Product innovation capabilities: Acquiring and using knowledge to develop innovative products American Marketing Association”. Conference Proceedings; 2002; 13, ABI/INFORM Collection. pg. 372

Wonglimpiyarat J. (2010). "Innovation Index and the Innovative Capacity of Nations". Future (2010). 247-253. doi:10.1016/j.futures.2009.11.010 